\title{
Renewable Energy: The Future of Bangladesh
}

\author{
Md. Mamunur Rahman*, Nahid Nasrin*, Swarup Chakraborty*, Md. Asif \\ Siddique*, Subrata Bhowmik**, Rukhesh Barua*** \\ *(Lecturer, Department of EEE, Port City International University, Bangladesh Email: \\ md.mamunurrahman37@yahoo.com, \\ nahid.nasrin@yahoo.com,swarup1103@gmail.com,asifsiddiquebzs@gmail.com) \\ **(B.Sc. in EEE, Chittagong University of Engineering and Technology, Bangladesh, Email: \\ subratabhowmik.ndc.eee.11.cuet@gmail.com.) \\ *** (B.Sc. Student, Department of EEE, Port City International University, Bangladesh, Email: \\ abhimanbarua@gmail.com)
}

\begin{abstract}
Electrical energy is versatile and considered as the back bone of our daily life. It is directly or indirectly used in everyone's daily activities. But for having the availability of the sources, we cannot but depend on the renewable resources. The renewable resources can be replaced through the natural process at a rate which is equal or greater than this rate at which they are used. Actually, renewable energy is generated from natural resources like sunlight, wind, tide, geothermal heat, ocean energy etc. that are renewable. A prediction is that in 2030, energy comes from renewable sources is $28 \%$ of total generation. Though Bangladesh having lots of natural resources, but still now facing and struggling with the shortage of power, while our neighboring countries are utilizing their sources properly and being richer with better economic growth. The vision for increasing economic growth to $10 \%$ by 2017 can be come into reality through the proper utilization of renewable energy resources for having a sustainable development of our country. This paper shows an analytical study on recent energy scenario of Bangladesh and describes the potentiality of available renewable energy resources that should be incorporated in the national energy planning.
\end{abstract}

Keywords: Biomass, Hydro, Nuclear, Renewable Energy, Solar, Wind.

\section{I.INTRODUCTION}

Bangladesh is placed at the southern Asia with having neighboring countries like India in west \& east, Myanmar in the south-east end and the Bay of Bengal in south with its population of around 17 crores in the land means of $148460 \mathrm{~km}^{2}$. Bangladesh, an emerging nation is successfully maintaining economic growth of $6.7 \%$ and led to high demand of electricity each year since the last decade [1]. But due to misuse, inadequate production and the management of energy both in the past and present, the actual demand cannot be fulfilled. So, load shedding has become a daily opinion and increased to an extensive and high extent. Just $59.60 \%$ of Bangladeshis are having access to the electricity, where the energy in per capita use is only 180 kilowatt-hours and that is quite low compared to others country[2].The people of countryside areas are not getting the facilities of power than urban people for this shortage .However, Bangladesh is a country which is so dependent on predictable energy sources such as gas ,hydro-power , oil etc. which cannot meet the challenge of the upcoming demand if renewable resources cannot be considered and cannot be utilized [3].

\section{II.CURRENT ENERGY SCENARIO IN BANGLADESH}

At present both in cities and rural areas, Bangladesh is facing a huge scarcity of electricity. Only two third of whole population have been access to electricity with capita of $279 \mathrm{KW}-\mathrm{Hr}$ per annum [4]. There are so many difficulties like security concerns on growing fuel imports, highly dependence on the energy resources like coal, gas that has inadequate growth of electricity production. We cannot but depend on natural gas almost $62 \%$ [5]. At present, Bangladesh has a state of power which is about $12578 \mathrm{MW}$ where the generation is about $8305 \mathrm{Mw}$ in March,2017. Overall installed capability of BPDB power plants as on February 2017was 15379 MW. The Fig. 01 at below shows that the installed capacity of BPDB power plant as on February 2017[6]. 
Installed Capacity as on February, 2017

(By Fuel Type)

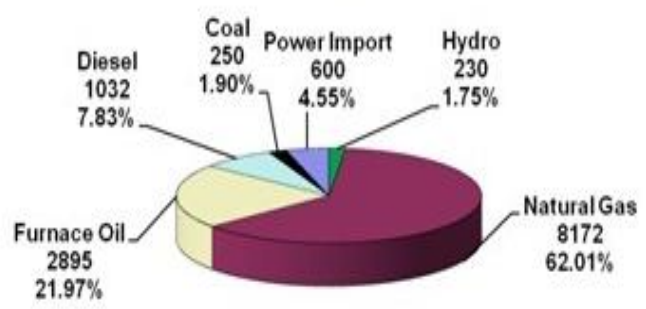

Figure 01: Installed power capacity scenario

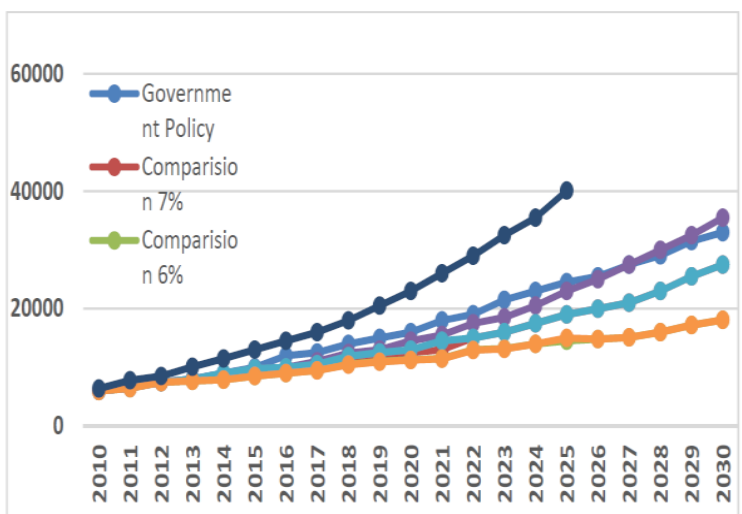

Figure 02: Study year-wise peak demand forecast

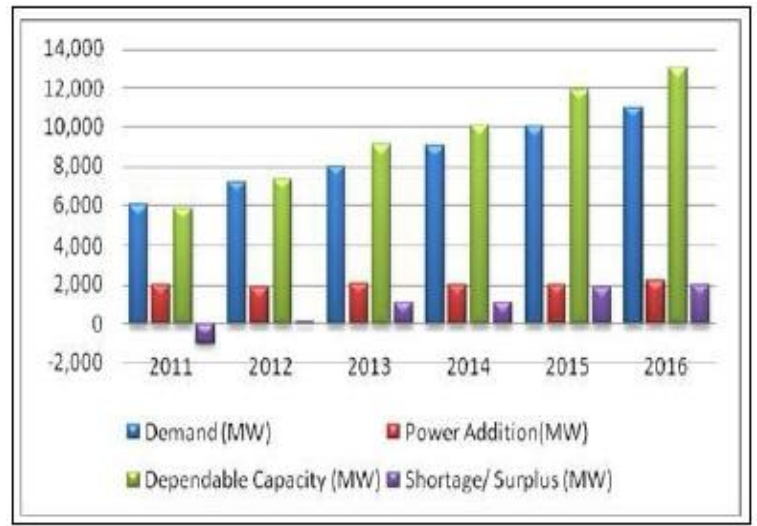

Figure 03: Power shortage for a period of seven years

The likely additional of electricity in time of $2011-2016$ is in Fig. 03[8]. While the demand for electricity is increasing, the production capacity of existing power stations does not increase to meet this demand. By using renewable energy sources such as air, waste and solar energy, Bangladesh has intended to fabricate $10 \%$ of total power production by 2020 [9].

\section{III.PROSPECTIVE RENEWABLE ENERGY SCENARIO}

In terms of renewable energy sources such as solar, biomass, wind etc. Bangladesh is really blessed with lots of supply. But there is a subject of distress that, Bangladesh is not still capable of make the proper use of its resources for making the power accessible for the people. Thought if we compare to the fossil fuel alternative, the expenditure of investment of renewable energy technology goes high. And when environmental cost, health hazards etc. lower operating expenses are in concern, this option is an economically noticeable. The advantage of renewable energy is that is gracious with environment and very suitable for developing countries like ours which is in the risk of climate contamination. But, good news is that, Govt. is trying greatly undertaking plans to combine the renewable energy so the entire country can meet their desired power demand. Some private companies are trying to strap up the huge probable of the renewable energy in Bangladesh. [10].

\subsection{Solar Energy}

Solar power is an energy which is from the sun and is converted into thermal or electrical energy. This is the most plentiful and the purest renewable energy source which is available in our environment. The adaptation of the sunlight to electricity either using photovoltaic or using concentrated solar power is actually the solar power. Although initial investment fee is high, the operating fee is very low. Bangladesh is a semitropical country which is lied within 20.30 to 26.38 degrees in north latitude and in the east, it's within 88.04 to 92.44 degree shaving with adequate sunshine in which the daily average solar radiation range is $4-6.5 \mathrm{KWh} / \mathrm{m}^{2}$. There is a Table 01, shows the solar radiation data for various month throughout the year in Raujan, Chittagong, Bangladesh, as below [11].

In this solar radiation chart, described in Table 01, it's found that on May \& June, the maximum solar radiation is found which is about $5.786 \mathrm{KW} / \mathrm{m}^{2} /$ day and the minimum radiation is on the month of August where the daily radiation is about $4.048 \mathrm{KW} / \mathrm{m}^{2} /$ day. And the average radiation is $4.758 \mathrm{KW} / \mathrm{m}^{2} /$ day throughout a year. 
Table 01: Solar radiation throughout the year

\begin{tabular}{|c|c|c|}
\hline Month & $\begin{array}{c}\text { Clearness } \\
\text { Index }\end{array}$ & $\begin{array}{c}\text { Daily } \\
\text { Radiation } \\
\left(\mathrm{KW} / \mathrm{m}^{2} / \mathrm{d}\right)\end{array}$ \\
\hline April & 0.646 & 4.597 \\
\hline February & 0.628 & 5.126 \\
\hline March & 0.596 & 5.634 \\
\hline April & 0.550 & 5.760 \\
\hline May & 0.527 & 5.786 \\
\hline June & 0.390 & 5.786 \\
\hline July & 0.368 & 4.335 \\
\hline August & 0.398 & 4.048 \\
\hline September & 0.418 & 4.224 \\
\hline October & 0.555 & 4.083 \\
\hline November & 0.601 & 4.725 \\
\hline December & 0.649 & 4.409 \\
\hline Average & 0.513 & 4.758 \\
\hline
\end{tabular}

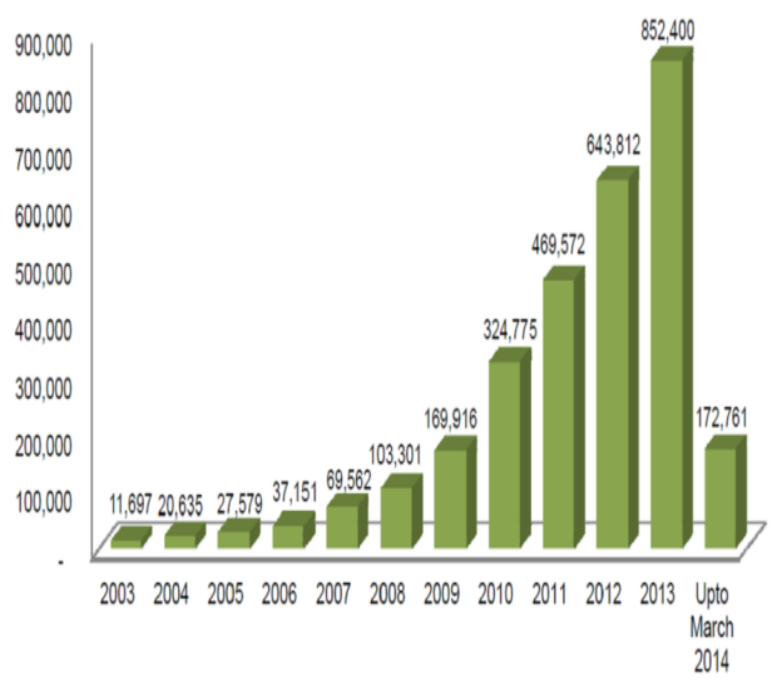

Figure 04: Year wise SHS System

For this in Bangladesh, the IDCOL has installed 4.1 million SHS up to October 2016 in the remotest areas which is precious and tough because of electrification through grid development and has a target to finance 6 million SHS by 2021 which will able to generate $220 \mathrm{MW}$ of electricity on an approximation. In the Fig. 04, showing the number of the creation of Solar Home System for few years by Infrastructure Development Company Limited (IDCOL) [12].

Recently, in more than $50 \%$ of about 10,000 commercial markets and different rural markets, the national grid energy is greatly contributing to centralize the solar photovoltaic plants. For habitual means candles, oil lamps, kerosene etc. are used in various houses, offices and different institutions in off grid and in a few places own diesel generator are used to produce electricity which should be brought under solar technologies like solar pond, solar thermal, solar water heater, solar air heater, solar cooker \& solar vehicle etc.

\subsection{Wind Energy}

Wind is a good source of renewable energy. For having a long coastal area, Bangladesh is suitable for it. Here in different seasons wind blows in several patterns. In the time of monsoon from Indian Ocean, the heavy south-westerly wind comes which passes coastal areas of Bangladesh. For this reason, in the time of March to September, the average speed of wind is $3 \mathrm{~m} / \mathrm{s}$ to $6 \mathrm{~m} / \mathrm{s}$ and similarly this rate remains lower during October to February. And in the time of June to July, maximum wind speed can be seen [13]. So, it would be better if wind turbine is established in the coastal areas and it will be the solution to meet up our demand supporting the national grid. According to the statistical data, Bangladesh Govt. has made a project which is named as Wind Energy Study Project (WEST) where, on the six potential coastal areas, the average wind speed is recorded for a year is like as Fig. 05 [14].

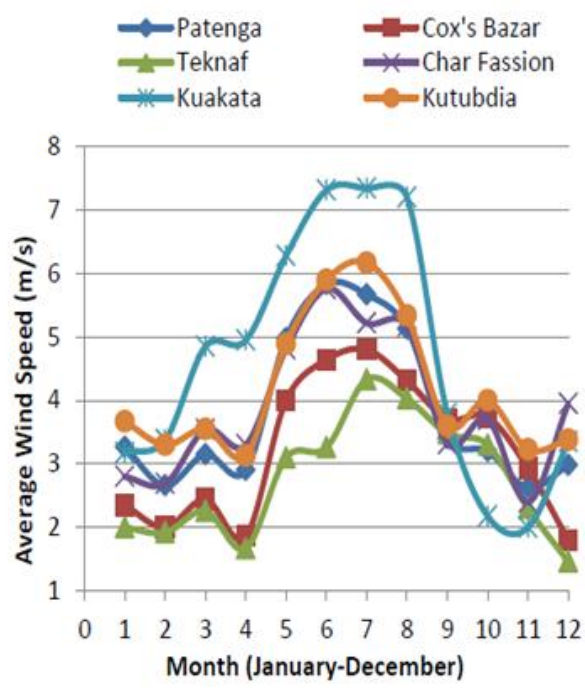

Figure 05: Average Wind Speed in Six Different Coastal Spots (Monthly)

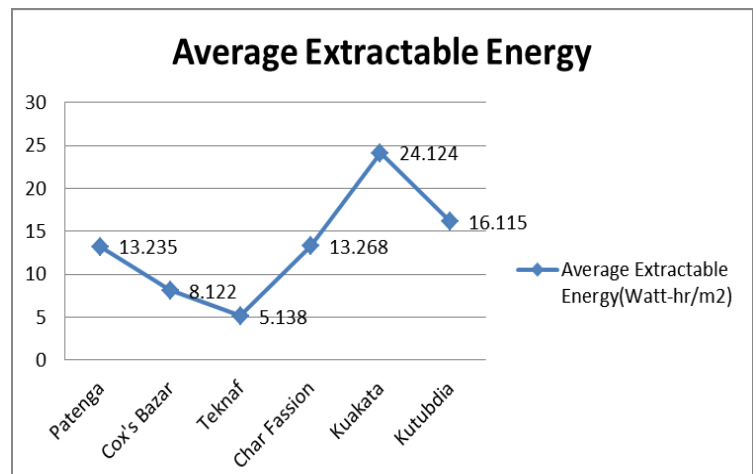

Figure 06: Average Extractable Wind at six WEST stations 


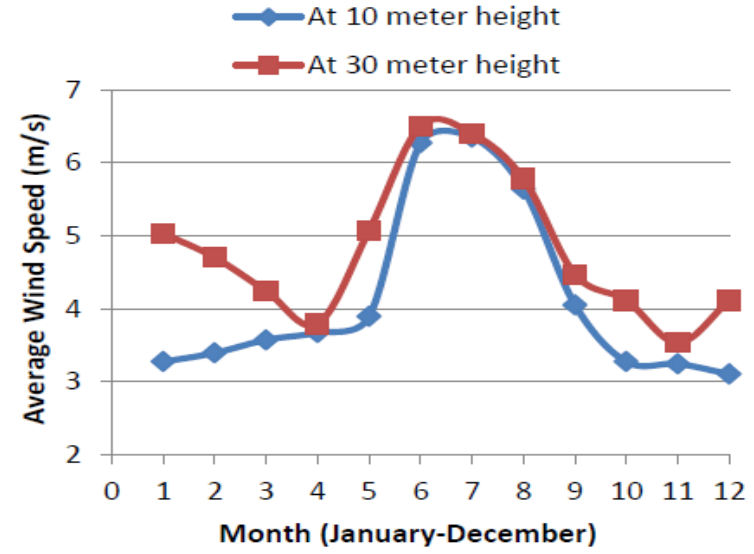

Figure 07: Monthly average wind speed difference according to height of the of tower.

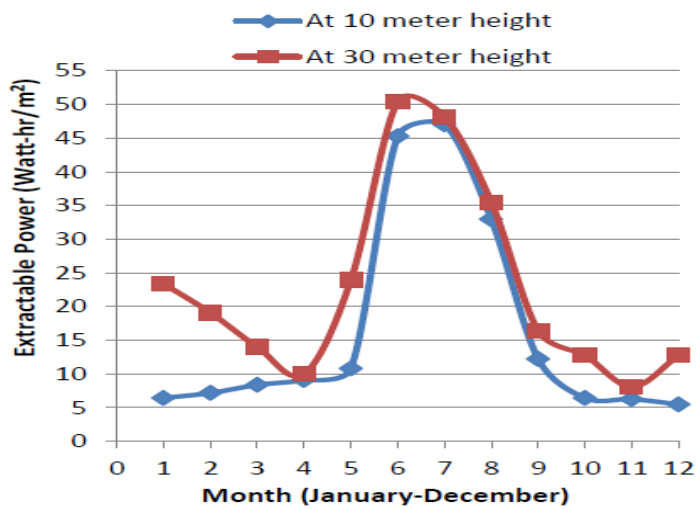

Figure 08: Extractable power difference according to height of the of tower

And average extractable wind energy is shown in the following Fig. 06. There is also an effect of height on power extraction from wind turbine. The average wind speed is higher with the increased height. From a study from BMD, applied in Saint Martin Island showed that if the height of the existing towers is increased from 10 to 30 meters, then more than $39 \%$ power can be more extracted with respect to the present one [15].

\subsection{Ocean Wave Energy}

From the ocean's wave, the ocean's wave energy is directly produced. This is obviously an energy which can help eradicating the risky emission of greenhouse gas coping with the generation of power. For this, it's a significant and possible source of electricity in Bangladesh. 'The oscillating Water Column Method' is exactly possible and has become economically good in this purpose. Already, many countries are using this type of wave energy harnessing device [16].

\subsection{Tidal Energy}

Bangladesh is really blessed for having the Bay of Bengal and longer coastal belt which is about
740 KM. Tidal power be a clean renewable energy, is a suitable source of power in coastal area of Bangladesh [17]. The tidal power can be produced through the tidal stream generator [18]. Though this isn't widely used but has a potential for generating the electricity for future. So, tidal energy is greatly expected than the solar and wind energy [19]. For having recent, new development and establishment in turbine technology and plan, the new availability of tidal power can be greater and higher than the power that was previously assumed. Bangladesh having a sea in the south may gain more energy from the tidal waves by given application of two technologies, which are Low head tidal movement (2 to 5 meters' head) and Medium head tidal movement (5 meters or over) respectively [17].

Here, the tidal movement of low head can be established in the coastal areas like: Khulna, Satkhira, Barishal, Bagerhat, Cox's Bazar in the region with sluice gates and levees. In time of high tide if the water is trapped into a coastal basin and if a dead difference is created in the time of low tide to drive the turbine, this water heads could be easily used. Many developed countries are using this method [20].

\subsection{Hydro Power}

Hydropower is an energy source which is environment friendly. For being its land flat with of a few exception regions, Bangladesh has no opportunity of hydropower. During the monsoon season, the major rivers provide a high amount of water flow in 5 to 6 months, but in time of winter it's reduced [21]. For hydropower, the plant can be classified into 2 categories which are Large Hydropower Plants and Small Hydropower Plants.

Kaptai dam is only one dam of Bangladesh in which there is production of electricity by hydroelectric power plant. It's on the bank of Karnaphuli at Kaptai and $65 \mathrm{KM}$ away from Chittagong on Rangamati. The construction of Kaptai dam is started on 1962.The reservoir water storage capacity is 6477 million cubic meters and 230 Megawatts electricity when it runs on full capacity [22]. There are also 2 sites which are likely identified for another more hydropower.

Table 02: Prospective Hydro Power Plant Sites

\begin{tabular}{|c|c|c|}
\hline District & $\begin{array}{c}\text { Name } \\
\text { river/chara/stream }\end{array}$ & $\begin{array}{c}\text { Potential of } \\
\text { electrical } \\
\text { energy in KW }\end{array}$ \\
\hline Chittagong & Foy's Lake & 4 \\
\hline Chittagong & Chotokumira & 15 \\
\hline Chittagong & HinguliChara & 12 \\
\hline $\begin{array}{l}\text { Chittagong } \\
\text { Hill Tracts }\end{array}$ & Sealock & 81 \\
\hline Chittagong & Lungi Chara & 10 \\
\hline Chittagong & BudiaChara & 10 \\
\hline
\end{tabular}




\begin{tabular}{|c|c|c|}
\hline Sylhet & NikhariChara & 26 \\
\hline Sylhet & Rangapani Gung & 66 \\
\hline Jamalpur & $\begin{array}{c}\text { Bhugai-kongsa at } 2 \\
\text { miles U/S of } \\
\text { Nalitabari P. S }\end{array}$ & $\begin{array}{l}69 \mathrm{KW} \text { for } 10 \\
\text { months } \\
48 \mathrm{KW} \text { for } 2 \\
\text { months }\end{array}$ \\
\hline Jamalpur & $\begin{array}{c}\text { Marisi at Dukabad } \\
\text { near Jhinaigati } \\
\text { Thana Head } \\
\text { Quater }\end{array}$ & $\begin{array}{l}35 \mathrm{KW} \text { for } 10 \\
\text { months } \\
20 \mathrm{KW} \text { for } 2 \\
\text { months }\end{array}$ \\
\hline Dinajpur & $\begin{array}{c}\text { Dahuk at Burabari } \\
\text { Chawai at U/S of } \\
\text { Chawai L.L.P } \\
\text { Talam at U/S of } \\
\text { Talam L.L.P } \\
\text { Pathraj at Fulbari } \\
\text { Tangon at D/S of } \\
\text { Nargun L.L. } \\
\text { Punarbhaba at } \\
\text { Singraban }\end{array}$ & $\begin{array}{l}24 \\
32 \\
24 \\
32 \\
48 \\
11\end{array}$ \\
\hline Rangpur & $\begin{array}{c}\text { BhurikhoraChikli } \\
\text { at Nizbari } \\
\text { Fulkumar at } \\
\text { Raigang Bazar }\end{array}$ & $\begin{array}{l}32 \\
48\end{array}$ \\
\hline
\end{tabular}

plants and those are at the Sangu and the Matamuhuri. A recent study conducted by US based consultancy firm STI noted that two rivers in the Chittagong hill Tracts could potentially generate 140 MW. The study observed that 58.33 MW could be generated from the Sangu and 75 MW from the Matamuhury that are identified by BPDB. There are some potential small hydro sites identified by BPDB and BWDB which are described in Table 02[23].

\subsection{Biomass}

Bangladesh is an agricultural country. For this, there's available of a lot of agricultural residues. So, one of the most promising renewable energy resources are biomass resources. Bangladesh has a lot of biomass resources which can cover about $55 \%$ of the total energy that are needed for our country [24]. About 48\% of the total biomass is covered by the various types of residues and these residues are divided into two types: (1) Field residue, (2) Processing residue. If the ways of sustainable optimized processes are invented, huge amount of energy can be got from waste like: crop residues, sugarcane biogases, rice husk, jute sticks etc. About $42 \mathrm{MT}$ agricultural crops residues are got annually in Bangladesh from which $37 \%$ and $63 \%$ are respectively process residue and field residue [25]. If we think about wood and wood wastes, there are leaves, roots, twigs, planer shavings, barks etc. which can confirm $100 \%$ recovery factor and annually recoverable amount is about 8.871 MT [25]. About 5000 poultry firm (commercial) are there in our Bangladesh from where huge amount of poultry wastes are got daily. For the poultry dropping the recovery factor is $50 \%$ and $60 \%$ is for animal waste with about 20619 MT of recoverable animal wastes and poultry dropping [26]. Besides, from the municipal solid waste and people produced solid wastes, a huge amount of energy can be generated. A statistical data by The World Bank says that $0.15 \mathrm{~kg} / \mathrm{capita} /$ day is the rate of the production in rural and $0.4-0.5 \mathrm{~kg} /$ capita/days is in urban areasfrom where recovery factor is $100 \%$ and the amount that is estimated is about 14.793MT and a one $\mathrm{kg}$ of dung can produce $0.037 \mathrm{~m} 3$ of biogas and the available of the cattle dung can easily produce 2.50 billion $\mathrm{m} 3$ gas which is same as $1.28 \mathrm{MT}$ of kerosene or 2.56 MT of coal [25] [26]. And as a report of IRRD, about a 4 million biogas plants can be established throughout the country. From where $75 \%$ is based on cow dung and $20 \%$ on poultry wastes and left $5 \%$ is on another biomass [27].

\subsection{Nuclear Energy}

As Bangladesh is having shortage of electricity, so she's needed a powerful and obviously established source to supply energy for a period of extended time continuously. For this problem, nuclear energy may be a solution. No other plants are as high as a typical nuclear power plant for it's the lifetime. Uranium is plentiful and technologies survive which can extend its use 60-fold if the demand needs it. And 6000 tons in a year is the world mine production. sFrom several sources like: stockpiles, lots of markets are given supply. Most of the supplies are used for electricity. The typical heat value of various fuels is given in Table 03 for making comparison [28].

In Bangladesh, for the first nuclear power plant, Roppur site was selected in 1963 and in 2001, our country got a national nuclear power action plan. At last in 2010, Bangladesh made an agreement for making a nuclear power plant with Russia to generate $2400 \mathrm{MW}$ which has two reactors and each reactor can able to produce $1200 \mathrm{MW}$ of power [29]. It's build on Roppur at the side of the Padma and the Ishwardi which is the sub district of Pabna. The cost was estimated to us $\$ 14$ billion to set up the Roppur nuclear plant. For the implementation of this project, the Bangladesh Atomic Energy Commission (BAEC) is being played of the role. GEN3/GEN3+ reactor system should be followed by Bangladesh which is based on the technical information and proven technology for the given consideration like: 1.Digital instrumentation and control system 2.Latest safety code for reducing severe accidents, such as Chernobyl, Fukushima disaster and Psychological and physical protection. 
Table 03: The Calorific Values of Various Fuel

\begin{tabular}{|c|c|}
\hline Ingredients & Calorific value \\
\hline Natural Gas & $38 \mathrm{MJ} / \mathrm{m} 3$ \\
\hline Crude Oil & $45-46 \mathrm{MJ} / \mathrm{kg}$ \\
\hline Black coal (hard) & $24-30 \mathrm{MJ} / \mathrm{kg}$ \\
\hline Black coal (low quality) & $13-23 \mathrm{MJ} / \mathrm{kg}$ \\
\hline Brown coal (lignite) & $10 \mathrm{MJ} / \mathrm{kg}$ \\
\hline Firewood (dry) & $16-18 \mathrm{MJ} / \mathrm{kg}$ \\
\hline $\begin{array}{c}\text { Uranium - in typical } \\
\text { reactor }\end{array}$ & $\begin{array}{c}500,000 \mathrm{MJ} / \mathrm{kg} \text { (of } \\
\text { natural U) }\end{array}$ \\
\hline
\end{tabular}

3.Simplicity and economically liable and safety consideration.

For this Roppur nuclear project is based on the proven technology records, Russion VVR-1000 MW/VVER-1200 MW nuclear system may be considered. According to the agreements, Russia will assist with all assistance to set up the plant including fuel and take back the used fuel and the plant may be gone into operation by 2021 by the 1 st unit and 2025 by the 2 nd unit [30].

\section{IV.FUTURE PLAN}

As a developing country, Bangladesh need more power according to the demand. For reducing the shortage of power, Bangladesh need more production with establishing new small and big power plant. Keeping this subject in mind, Bangladesh government and some private companies has made some projects. IDCOL has proposed to fund 50 solar mini grid schemes with having the combined financial partnership with $\mathrm{ADB}$ and WORLD BANK by 2017. At Rangunia, Chittagong, $60 \mathrm{MW}$ solar park project will be planted on IPP basis at Karnafuli River, by BPDB. Line this 40-45 MW solar park project will be on Tangail, Sirajgong area and $2-3 \mathrm{MW}$ at Ishwardi. In term for establishing $15 \mathrm{MW}$ wind power plant at the coastal areas of Bangladesh, some steps have been taken in which at Muhuri Dam and Mognamaghat respectively on Feni and Cox's bazar, the wind mapping is being gone on.50- $200 \mathrm{MW}$ wind power project will be set up on Anowara in Chittagong and has also a plan to expand the onshore wind power plants in the coastal region in Bangladesh. Besides, $1 \mathrm{MW}$ off grid solar diesel based on Hybrid power plant in Kutubdia Island is a plan for setting up by BPDB. And another big power plant, Rampal power plant is a future plan to generate electricity in Bangladesh which will generate $1320 \mathrm{MW}$ coal fired power station. Like this another new project named Maheshkhali coal fired power generation project will be installed to generate $1320 \mathrm{MW}$ [31].

\section{V.CONCLUSION}

The total development of a civilization is greatly depending on the electrical energy. Seeing per capital utilization of this energy, the total advancement can be easily realized. One of the most significant strategies cannot but be the improvement of the renewable energy. For generating the power, Bangladesh has to depend on fossil fuel yet now but these dependent resources are very limited. Through the carbon trading concept and changing global climate, renewable energy can make a significant contribution. This is the absolute time to go ahead and make a contribution in these renewable energy resources for generating electricity which include solar, wind, biomass, hydro-power etc. Bangladesh can produce electricity with the assist of these resources and will be capable of meeting the demand in future. For this, the Government coping with the Private companies have to contribute equally to highlight more on the renewable energy resources for the production of electricity to resolve our power calamity problem.

\section{REFERENCES}

[1]. About Economic growth, available at: www.powerdivision.gov.bd/user/brec/49/89 (01 April ,2017).

[2]. About Per Capita Energy Use, available at: www.bpdb.gov.bd/bpdb/index.php?option $=c 0$ m_content\&view=article\&id=151\&Itemid=11 8(01 April,2017).

[3]. About Energy Scenario, available at: www.phulbarinews.wordpress.com/2008/08/2 0/revisiting-the-energypower-scenario-in Bangladesh (02 April,2017).

[4]. About Energy Access, available at: http://data.worldbank.org/indicator/EG.USE. ELEC.KH.PC(03 April,2017).

[5]. About Bangladesh's Energy Situation, available at: https://energypedia.info/wiki/Bangladesh_Ene rgy_Situation(04 April,2017).

[6]. About Installed Capacity of BPDB, available at:

http://www.bpdb.gov.bd/bpdb/index.php?opti on=com_content $\&$ view=article \&id=150\&Ite mid=16 (05 April, 2017).

[7]. About Year Wise Peak Demand Estimation, available at: www.bpdb.gov.bd/PSMP/PSMP2010.pdf(08 April, 2017).

[8]. About Power Shortage, available at: http://www.mof.gov.bd/en/budget/11_12/pow er/power_energy_en.pdf(08 April ,2017).

[9]. Amin, E.M., Sharin, A., Islam, R. and Chowdhury, S.A., Renewable Energy Scenario of Bangladesh: Physical Perspective, 1st International Conference on 
the development in Renewable Energy Technology (ICDRET), 2009.

[10]. About Government Budget on Renewable Energy, available at: www.mof.gov.bd/en/budget/power_energy.pd f(08 April, 2017).

[11]. Anik Deb, Dr. Mahmud Abdul Matin Bhuiyan and Arefin Nasir, Prospects of Solar Energy in Bangladesh, IOSR Journal of Electrical and Electronics Engineering (IOSR-JEEE),4(5), 2013,46-57.

[12]. About IDCOL, available at: http://www.idcol.org(10 April, 2017).

[13]. A.Z.A. Saifullah, Md. Abdul Karim and Md. Raisul Karim, Wind Energy Potential in Bangladesh, American Journal of Engineering Research (AJER), e-ISSN: 2320 0847, p-ISSN: 2320-0936, 5(7), 2016,85-94.

[14]. About WEST Project, available at: www.asiatradehub.com/bangladesh/oil2.asp(1 1 April, 2017).

[15]. Md. Tanjin Amin, Prospects of Wind Energy in Bangladesh, International Journal of Advanced Renewable Energy Research, 2(8), 2015, 213-218.

[16]. About Ocean Wave Energy, available at: http: //www.bpedia. org/R_0175.php (13 April,2017).

[17]. Tausif Ali, Muhammad Omar Faruk, Sabuj Das Gupta and Kamrul Hasan, Perspective and Prospect of Tidal Energy in Bangladesh, International Journal of Scientific \& Engineering Research, ISSN 2229-5518, 3(7), 2012.

[18]. T. J. Hammons, Tidal power, Proceedings of the IEEE, 81(3), 2004,419-433.

[19]. R. Lecomber, The evaluation of tidal power projects, in Tidal Power and Estuary Management, eds. Severn, R. T., Dineley, D.L. \& Hawker, L. E., Henry Ling Ltd., Dorchester, 1979,31-39.

[20]. About Tidal Energy Harvesting Method, available at: www.banglapedia.org (16 April, 2017).

[21]. Ahmed, Investigation and Analysis of Wind Pumping System for Irrigation in Bangladesh, M.Sc. Engineering Thesis, BUET, Dhaka, Bangladesh,2000.

[22]. About Kaptai Dam, available at: http://mirrorofbd.blogspot.com/kaptai-dam karnafuli-hydro-power.html (17April, 2017).

[23]. Jahidul Islam Razan, Riasat Siam Islam, Rezaul Hasan, Samiul Hasan, and Fokhrul Islam, A Comprehensive Study of MicroHydropower Plant and Its Potential in Bangladesh, International Scholarly Research Network ISRN Renewable Energy, Article
ID:635396, 2012, pp 10 . Doi: $10.5402 / 2012 / 635396$.

[24]. M.A. Wazed and M. A. Islam, Prospect and future of biomass fuel: a review in Bangladesh perspective, Engineering $e$ Transaction (ISSN: 1823 - 6379),5, 2010, 6166.

[25]. M. Rofiqul Islam, M. Rabiul Islam and M. Rafiqul Alam Beg, Renewable Energy Resources and Technologies Practice in Bangladesh, Renewable and Sustainable Energy Reviews, Publisher: Elsevier .22(2), 2008, 299- 343, Doi:10.1016/j. r j er.2006.07.03.

[26]. About Poultry waste, available at: http://www.pub.iaea.org. (19 April, 2017).

[27]. M.A. Matin, H. Rahman, M. R. Hossain, M.A. Eshan, G.M. Hossain, and M. M. I. Mahfuj, Present Scenario and Future Prospect of Renewable Energy in Bangladesh, 1st International Conference on Physics for Sustainable Development \& Technology (ICPSDT), 2015.

[28]. About Calorific Value of Nuclear fuel, available

at:http://www.world-nuclear.org/info/Nuclear -Fuel-Cycle/Introduction/Energy-for-the-Wor ld---Why-Uranium/(19 April, 2017).

[29]. A. S. Mollah, Sabiha Sattar, M. A. Hossain, A.Z.M. Salahuddin and H. AR-Rashid, Prospects of Nuclear Energy for Sustainable Energy Development in Bangladesh, International Journal of Nuclear Energy Science and Engineering (IJNESE),5(7), 2015, DOI: 10.14355/ijnese.2015.05.00.

[30]. About Nuclear Power Plant in Bangladesh, available at: http://www.worldnuclear.org/Country-Profiles/Countries-AF/Bangladesh (20 April, 2017).

[31]. About Coal Power Plant in Bangladesh, available at:www.bpdb.gov.bd/bpdb/index.php?option= com_content $\&$ view=article $\&$ id $=26 \&$ Itemid $=2$ 4(20 April, 2017). 